\title{
KARAKTERISTIK DAN STATUS KETERGANTUNGAN PEROKOK AKTIF TERHADAP NIKOTIN DI KOTA YOGYAKARTA
}

\author{
Eliza Dwintaํㅜㄴ Latifah Iman Sari $^{1}$, Mutiara Wayu Puspasari ${ }^{1}$ \\ ${ }^{1}$ Program Studi Farmasi; Fakultas IImu-ilmu Kesehatan; Universitas Alma Ata. \\ Email: elizadwinta@almaata.ac.id, latifahimansari838@gmail.com, mutiarawayu49@gmail.com

\section{Korespondensi:} \\ Eliza Dwinta \\ Program Studi Sarjana Farmasi, Fakultas Ilmu-IImu Kesehatan, Universitas Alma Ata \\ elizadwinta@almaata.ac.id
}

\begin{abstract}
Abstrak
Rokok mengandung unsur-unsur kimia seperti tar, nikotin, benzovrin, metalkloride, aseton, amino, dan karbon monoksida. Adanya kandungan nikotin dalam rokok dapat menyebabkan ketergantungan. Fagerstrom Test for Nicotine Dependence (FTND) digunakan sebagai kuisioner bagi para perokok di daerah Yogyakarta untuk mengetahui tingkat ketergantungan terhadap nikotin. Penelitian ini merupakan deskriptif dengan pendekatan cross-sectional. Responden sejumlah 70 perokok aktif dengan hasil karakteristik demografis, yaitu $(97,1)$ laki-laki dan $(2,9)$ perempuan, dan awal mula masyarakat merokok yaitu pada usia 17-25 tahun dengan pendidikan terakhir SMA sederajat. Penghasilan perokok melalui penelitian ini didapatkan sebesar Rp 1.000.000,00 hingga Rp 2.000.000,00. Dari 70 perokok terdapat $40 \%$ perokok ketergantungan nikotin rendah hingga sedang, 34,3\% responden memiliki ketergantungan rendah; $21,4 \%$ responden memiliki tingkat ketergantungan sedang, dan 4,3\% responden memiliki tingkat ketergantungan tinggi terhadap nikotin. Tujuan dari penelitian ini adalah mengetahui status ketergantungan perokok aktif terhadap nikotin di wilayah Kota Yogyakarta. Status ketergantungan terhadap nikotin dapat dijadikan salah satu kriteria dalam menentukan sasaran promosi kesehatan oleh tenaga kesehatan terkait merokok. Sasaran dan metode promosi kesehatan yang tepat dapat memudahkan informasi tersampaikan guna meningkatkan kesadaran perokok terhadap kesehatan tubuhnya.
\end{abstract}

Kata Kunci: fagerstrom test for nicotine dependence; status perokok; perokok aktif

\section{CHARACTERISTICS AND STATUS OF ACTIVE SMOKER DEPENDENCE ON NICOTINE IN YOGYAKARTA}

\begin{abstract}
Cigarettes contain chemical elements such as tar, nicotine, benzovrin, metalchloride, acetone, amino, and carbon monoxide. The presence of nicotine in cigarettes can cause dependence. The Fagerstrom Test for Nicotine Dependence (FTND) was used as a questionnaire for smokers in the Yogyakarta area to determine the level of dependence on nicotine. This research is a descriptive cross-sectional approach. Respondents were 70 active smokers with the results of demographic characteristics, namely male (97.1\%) and female (2.9\%), and the beginning of the smoking community, namely at the age of 17-25 years with the latest high school education equivalent. The income of smokers through this research is obtained from $R p 1,000,000.00$ to $R p 2,000,000.00$. Of the 70 smokers, $40 \%$ of
\end{abstract}


Dwinta, Eliza

Karakteristik dan Status Ketergantungan Perokok Aktif terhadap Nikotin

smokers had low to moderate nicotine dependence; $34.3 \%$ of respondents had low dependence; $21.4 \%$ of respondents have a moderate level of dependence; and $4.3 \%$ of respondents have a high level of dependence on nicotine. The purpose of this study was to determine the nicotine dependence status of smokers in Yogyakarta. Nicotine dependence status can be used as one of the criteria in determining health promotion targets by health workers related to smoking. The right targets and methods of health promotion can make it easier for information to be conveyed in order to increase smokers' awareness of their health.

Keyword: fagerstrom test for nicotine dependence; dependence status of smokers; active smokers

\section{PENDAHULUAN}

Merokok adalah salah satu cara mengkonsumsi tembakau bagi para masyarakat diindonesia maupun dunia yang sering dijumpai ${ }^{1}$. Merokok juga merupakan salah satu masalah kesehatan yang belum diselesaikan diseluruh dunia, dampak yang terjadi pada perokok aktif maupun pasif dapat terlihat jelas pada kesehatan fisik manusia. Penyakit yang diderita oleh masyarakat melalui rokok yaitu disebabkan oleh adanya kandungan tembakau. Penyakit yang disebabkan oleh tembakau merupakan penyakit tidak menular, seperti masalah pernafasan, kanker, penyakit kardiovaskular dan lainnya².

Rokok mengandung unsur-unsur kimia seperti tar, nikotin, benzovrin, metalkloride, aseton, amino, dan karbon monoksida ${ }^{3}$. Menurut World Health Organization ${ }^{4}$ tahun 2019 ditingkat global ini lebih dari 22.000 orang meninggal dunia karena menggunakan tembakau atau terpapar asap rokok setiap harinya yaitu satu orang dalam 4 detik setiap harinya. Berdasarkan Riset Kesehatan Dasar 2014, sebesar 85\% rumah tangga diindonesia terpapar asap rokok, estimasinya adalah 8 perokok meninggal karena perokok aktif, 1 perokok pasif meninggal karena terpapar asap rokok orang lain. Maka dari perhitungan rasio sedikitnya 25.000 kematian diindonesia disebabkan oleh rokok. Dilihat dari data yang ada bahwa merokok berdampak pada kematian yang rasionya tidak kurang dari $20.000^{5}$. Kematian yang disebabkan oleh rokok dapat diperkirakan pada tahun 2015 lalu sekitar 6,4 juta jiwa dan pada tahun 2030 meningkat sekitar 8,3 juta jiwa. Perkiraan kematian akibat perokok pasif dan aktif tiap tahunnya meningkat dikarenakan banyaknya perokok pemula yang masih dibawah umur². Daerah Istimewa Yogyakarta (DIY) diketahui pada tahun 2017 masuk pada 15 besar provinsi dengan prevelensi perokok tertinggi 
(31,6\%). Dari seluruh perokok di DIY sebagian besar $(66,1 \%)$ diketahui merokok didalam rumah yang akan berdampak pada anggota keluarga lainnya ${ }^{6}$.

Kesehatan merupakan kunci utama kehidupan, namun hingga saat ini masih banyak perokok yang belum sadar akan kesehatan itu sendiri. Adanya kandungan nikotin dalam rokok yang mengakibatkan munculnya sebuah ketergantungan, karena nikotin merupakan stimulan psikomotor. Akibat efek yang ditimbulkan oleh nikotin, perokok akan merasakan sensasi tenang saat dalam keadaan stress dan membantu perokok untuk lebih berkonsentrasi, serta lebih efektif dalam bekerja ${ }^{7,8}$. Perokok yang menghentikan konsumsi rokok pada waktu tertentu akan merasakan efek withdrawal (putus zat), yaitu muncul gejala-gejala seperti cemas, merasa tertekan, mudah marah, mudah putus asa, dan depresi. Gejala-gejala tersebut akan muncul dan membuat perokok tidak nyaman, sehingga membutuhkan rokok untuk menghilangkan gejala-gejala tersebut, dan hal ini yang menyebabkan perokok memiliki ketergantungan terhadap nikotin ${ }^{9}$. Karena alasan ini, peneliti ingin mengetahui status ketergantungan perokok terhadap nikotin.

\section{METODE PENELITIAN}

\section{Populasi dan Sampel}

Populasi dalam penelitian ini adalah masyarakat di Kota Yogyakarta yang merokok di tempat umum. Subjek dalam penelitian ini adalah perokok aktif yang merokok di tempat umum wilayah Kota Yogyakarta dan bersedia menjadi responden. Teknik pengambilan sampel penelitian menggunakan metode purposive sampling. Perokok yang menjadi responden pada penelitian ini sebanyak 70 orang.

\section{Rancangan Penelitian}

Jenis penelitian ini adalah deskriptif dengan pendekatan cross-sectional. Instrumen yang digunakan adalah kuesioner Fagerstrom Test for Nicotine Dependence (FTND). FTND merupakan kuesioner dengan enam pertanyaan yang akan memberikan gambaran terhadap ketergantungan nikotin. Masing-masing pertanyaan memiliki skala nilai yang berbeda-beda, antara 0 sampai 3. Nilai dari masing-masing pertanyaan akan dijumlahkan. Total nilai dari 6 pertanyaan tersebut yang akan mendeskripsikan perokok memiliki ketergantungan terhadap nikotin. Perokok dengan ketergantungan rendah terhadap nikotin memiliki total nilai 1-2, perokok dengan ketergantungan rendah hingga sedang terhadap nikotin memiliki total nilai 3-4, perokok dengan ketergantung nikotin sedang memiliki total 
Dwinta, Eliza

Karakteristik dan Status Ketergantungan Perokok Aktif terhadap Nikotin

nilai 5-7, dan total nilai pengisian kuesioner FTND lebih besar sama dengan 8 ( $\geq 8)$ menggambarkan perokok memiliki ketergantungan tinggi terhadap nikotin. Forum Group Discussion (FGD) dilakukan untuk validasi kuesioner FTND yang diadaptasi dan dimodifikasi menjadi Bahasa Indonesia. Diskusi dilakukan dengan akademisi $(n=3)$.

\section{HASIL DAN PEMBAHASAN}

\section{Karakteristik Demografi Perokok di Kota Yogyakarta}

Responden sebanyak 70 perokok aktif mengisikan informed consent peneitian terlebih dahulu untuk menyetujui kesediaan menjadi responden. Pengisian kuesioner pada bagian pertama menggambarkan karakteristik demografi, meliputi jenis kelamin, usia (berdasarakan DepKes 2009), pendidikan terakhir, pekerjaan, pendapatan atau uang saku, dan usia awal mula responden merokok (Tabel 1).

Total 70 perokok aktif yang menjadi responden lebih banyak laki-laki dengan persentase $97,1 \%$ daripada perokok perempuan (2,9\%). Perokok berumur 17-25 tahun sebanyak 59 orang $(84,3 \%)$ menjadi reponden terbanyak dalam penelitian ini. Sebanyak 49 responden (70\%) menempuh pendidikan terakhir SMA sederajat. Responden dengan status pekerjaan sebagai mahasiswa sebanyak 54 orang $(77,1 \%)$ juga merupakan responden terbanyak dalam penelitian ini. Pendapatan atau uang saku responden terbanyak adalah antara $\mathrm{Rp} 1.000 .000,00$ sampai dengan $\mathrm{Rp} 2.000 .000,00$ sejumlah 34 orang $(48,6 \%)$. Awal mula responden merokok adalah pada usia 10-15 tahun (50\%).

Di Indonesia, terutama di wilayah Jawa, hampir semua laki-laki merokok karena mengikuti kebiasaan di lingkungannya. Merokok akan meningkatan kepercayaan diri seorang laki-laki, karena pemuda yang merokok akan lebih diterima oleh lingkungannya dan akan dianggap maskulin daripada pemuda yang tidak merokok. Para orang tua sudah mulai mengenalkan rokok kepada anak laki-lakinya yang berusia sangat dini, sekitar 10-12 tahun. Pengenalan rokok kepada laki-laki berusia muda melalui kegiatan-kegiatan perkampungan dan perkumpulan orang-orang dewasa yang merokok di depan mereka. Namun, tidak sedikit pula orang tua yang melarang anak laki-lakinya untuk tidak merokok hingga usia yang sudah dewasa dan bisa mencari uang sendiri, karena harga rokok yang tidak murah ${ }^{10}$. 
Tabel I. Karakteristik Demografi Responden

\begin{tabular}{|c|c|c|c|}
\hline Demografi & Karakteristik & $\begin{array}{c}\text { Frekuensi } \\
(n=70)\end{array}$ & $\begin{array}{c}\text { Persentase } \\
(n=70)\end{array}$ \\
\hline \multirow[t]{2}{*}{ Jenis Kelamin } & Laki-laki & 68 & 97,1 \\
\hline & Perempuan & 2 & 2,9 \\
\hline \multirow[t]{5}{*}{ Usia } & 12-16 tahun & 3 & 4,3 \\
\hline & 17-25 tahun & 59 & 84,3 \\
\hline & 26-35 tahun & 4 & 5,7 \\
\hline & 46-55 tahun & 2 & 2,9 \\
\hline & 56-65 tahun & 2 & 2,9 \\
\hline \multirow[t]{6}{*}{ Pendidikan Terakhir } & SD & 10 & 14,3 \\
\hline & SMP & 1 & 1,4 \\
\hline & SMA/SMK & 49 & 70 \\
\hline & D1/D2/D3 & 2 & 2,9 \\
\hline & D4/S1 & 6 & 8,6 \\
\hline & $\mathrm{S} 2$ & 2 & 2,9 \\
\hline \multirow[t]{5}{*}{ Pekerjaan } & Pelajar & 3 & 4,3 \\
\hline & Mahasiswa & 54 & 77,1 \\
\hline & Pegawai Swasta & 4 & 5,7 \\
\hline & Pegawai Negeri & 3 & 4,3 \\
\hline & Wirausaha & 6 & 8,6 \\
\hline \multirow[t]{5}{*}{ Pendapatan/Uang saku } & $<\operatorname{Rp} 1.000 .000,00$ & 21 & 30 \\
\hline & Rp 1.000.000,00 -Rp 2.000.000,00 & 34 & 48,6 \\
\hline & Rp 2.000.000,00 -Rp 3.000.000,00 & 6 & 8,6 \\
\hline & Rp 3.000.000,00 -Rp 4.000.000,00 & 3 & 4,3 \\
\hline & $>\operatorname{Rp} 4.000 .000,00$ & 6 & 8,6 \\
\hline \multirow[t]{4}{*}{ Usia Awal Merokok } & 10-15 tahun & 35 & 50 \\
\hline & 16-20 tahun & 31 & 44,3 \\
\hline & 21-25 tahun & 2 & 2,9 \\
\hline & 26-30 tahun & 2 & 2,9 \\
\hline
\end{tabular}

\section{Status Ketergantungan Terhadap Nikotin}

Tabel 2 menunjukkan frekuensi dan persentase tingkat ketergantungan responden terhadap nikotin. Hasil tersebut berdasarkan penjumlahan skor pada 6 pertanyaan yang tertulis pada kuesioner FTND. Pertanyaan-pertanyaan pada kuesioner FTND meliputi waktu yang dibutuhkan untuk merokok pertama kali setelah bangun tidur, apakah responden merasa kesulitan dalam menahan keinginan merokok di temapt yang dilarang untuk merokok, waktu yang paling sulit bagi responden untuk tidak merokok, banyaknya rokok yang dihisap dalam sehari, waktu yang digunakan lebih sering untuk merokok, dan apakah responden tetap merokok meskipun dalam keadaan sakit parah. Jawaban yang dipilih responden kemudian dijumlahkan, dan diperoleh status ketergantungan responden terhadap nikotin (Tabel 2). 
Dwinta, Eliza

Karakteristik dan Status Ketergantungan Perokok Aktif terhadap Nikotin

Tabel II. Persentase Ketergantungan Perokok Terhadap Nikotin dengan Pengisian Kuesioner FTND

\begin{tabular}{ccc}
\hline $\begin{array}{c}\text { Status Ketergantungan } \\
\text { Perokok Terhadap Nikotin }\end{array}$ & Frekuensi (n=70) & Persentase (n=70) \\
\hline Rendah & 24 & $34,3 \%$ \\
Rendah hingga sedang & 28 & $40 \%$ \\
Sedang & 15 & $21,4 \%$ \\
Tinggi & 3 & $4,3 \%$ \\
\hline
\end{tabular}

Sebanyak 28 responden (40\%) berstatus perokok dengan ketergantungan rendah hingga sedang terhadap nikotin. Dan hanya 3 responden $(4,3 \%)$ yang memiliki status sebagai perokok dengan ketergantungan tinggi terhadap nikotin (Tabel 2). Riwayat merokok yang dimiliki oleh orang tua dari seorang perokok berhubungan dengan tingkat ketergantungan terhadap nikotin, jumlah rokok yang dihisap setiap harinya, serta tingkat depresi dan kecemasan ${ }^{11}$. Perokok dengan tingkat ketergantungan tinggi terhadap nikotin lebih cenderung tidak bahagia bila dibandingkan dengan perokok yang memiliki status ketergantungan rendah terhadap nikotin. Perasaan tidak bahagia akan meningkatkan stress yang kemudian dapat mengakibatkan peningkatan keinginan untuk merokok ${ }^{12}$.

Pada masing-masing tingkat ketergantungan (Tabel 3), responden terbanyak adalah laki-laki dan usia responden terbanyak adalah 17-25 tahun. Pendidikan terakhir yang ditempuh responden dengan tingkat ketergantungan rendah, rendah hingga sedang, dan sedang adalah SMA sederajat dengan jumlah 21 (87,5\%), 18 (64,3\%), dan 10 (66,7\%) responden. Sebanyak 2 responden $(66,7 \%)$ memiliki tingkat ketergantungan tinggi terhadap nikotin. Tingkat pendidikan mencerminkan sikap dan kebiasaan dalam merokok. Perokok yang kurang berpendidikan kemungkinan hanya mementingkan kebutuhan ekonomi terhadap nilai uang. Mereka lebih cenderung membutuhkan rokok untuk merasakan sensasi rileks dan akan menguatkan keinginan mereka untuk merokok. Keinginan tersebut yang membuat mereka berani mengeluarkan uang sakunya untuk membeli rokok daripada kebutuhan lain. Hal ini yang menyebabkan mereka menjadikan rokok sebagai kebutuhan primer $^{13,14}$.

Tabel 3 menunjukkan bahwa 21 responden (87,5\%) perokok dengan ketergantungan rendah terhadap nikotin, 17 responden $(60,7 \%)$ pada tingkat ketergantungan rendah hingga sedang, 13 responden $(86,7 \%)$ yang memiliki ketergantungan sedang, dan 3 responden (100\%) yang memiliki ketergantungan tinggi terhadap nikotin berstatus sebagai mahasiswa. Menjadi mahasiswa merupakan sebuah peluang untuk memperluas hubungan pertemanan, yang membuat mahasiswa mudah terpengaruh karena ingin diterima di sebuah lingkungan. Lingkungan pertemanan dengan 
perokok akan semakin menguatkan keinginan untuk merokok, meningkatkan kepercayaan diri karena merasa di terima di lingkungan tersebut ${ }^{15}$.

Tabel III. Karakteristik Perokok Berdasarkan Tingkat Ketergantungan Terhadap Nikotin

\begin{tabular}{|c|c|c|c|c|c|}
\hline \multirow[b]{2}{*}{ Demografi } & \multirow[b]{2}{*}{ Karakteristik } & \multicolumn{4}{|c|}{ Frekuensi (Persentase) } \\
\hline & & $\begin{array}{l}\text { Rendah } \\
(n=24)\end{array}$ & $\begin{array}{l}\text { Rendah } \\
\text { hingga } \\
\text { sedang } \\
(n=28)\end{array}$ & $\begin{array}{l}\text { Sedang } \\
(n=15)\end{array}$ & Tinggi $(n=3)$ \\
\hline \multirow[t]{2}{*}{ Jenis Kelamin } & Laki-laki & $22(91,7 \%)$ & $28(100 \%)$ & $15(100 \%)$ & $3(100 \%)$ \\
\hline & Perempuan & $2(8,3 \%)$ & - & - & - \\
\hline \multirow[t]{6}{*}{ Usia } & 12-16 tahun & - & $3(10,7)$ & - & - \\
\hline & 17-25 tahun & $23(95,8 \%)$ & $20(71,4 \%)$ & $13(86,7 \%)$ & $3(100 \%)$ \\
\hline & 26-35 tahun & - & $3(10,7 \%)$ & $1(6,7 \%)$ & - \\
\hline & 36-45 tahun & - & - & - & - \\
\hline & 46-55 tahun & $1(4,2 \%)$ & $1(3,6 \%)$ & - & - \\
\hline & $56-65$ tahun & - & $1(3,6 \%)$ & $1(6,7 \%$ & - \\
\hline Pendidikan & SD & - & $5(17,9 \%$ & $3(20 \%)$ & $2(66,7 \%)$ \\
\hline \multirow[t]{5}{*}{ Terakhir } & SMP & - & $1(3,6 \%)$ & - & - \\
\hline & SMA/SMK & $21(87,5 \%)$ & $18(64,3 \%)$ & $10(66,7 \%)$ & - \\
\hline & D1/D2/D3 & $2(8,3 \%)$ & - & - & - \\
\hline & $\mathrm{D} 4 / \mathrm{S} 1$ & - & $3(10,7 \%)$ & $2(13,3 \%)$ & $1(33,3 \%)$ \\
\hline & $\mathrm{S} 2$ & $1(4,2 \%)$ & $1(3,6 \%)$ & - & - \\
\hline \multirow[t]{5}{*}{ Pekerjaan } & Pelajar & - & $3(10,7 \%)$ & - & - \\
\hline & Mahasiswa & $21(87,5 \%)$ & $17(60,7 \%)$ & $13(86,7 \%)$ & $3(100 \%)$ \\
\hline & Pegawai Swasta & - & $3(10,7 \%)$ & $1(6,7 \%)$ & - \\
\hline & Pegawai Negeri & $1(4,2 \%)$ & $1(3,6 \%)$ & $1(6,7 \%)$ & - \\
\hline & Wirausaha & $2(8,3 \%)$ & $4(14,3 \%)$ & - & - \\
\hline Pendapatan/ & $<\operatorname{Rp} 1.000 .000,00$ & $8(33,3 \%)$ & $10(35,7 \%)$ & $3(20 \%)$ & - \\
\hline \multirow[t]{4}{*}{ Uang saku } & $\begin{array}{c}\text { Rp } 1.000 .000,00- \\
\text { Rp } 2.000 .000,00\end{array}$ & $15(62,5 \%)$ & $10(35,7 \%)$ & $8(53,3 \%)$ & $1(33,3 \%)$ \\
\hline & $\begin{array}{c}\text { Rp 2.000.000,00 - } \\
\text { Rp 3.000.000,00 }\end{array}$ & - & $4(14,3 \%)$ & $2(13,3 \%)$ & - \\
\hline & $\begin{array}{c}\text { Rp 3.000.000,00 - } \\
\text { Rp 4.000.000,00 }\end{array}$ & - & $1(3,6 \%)$ & $1(6,7 \%)$ & $1(33,3 \%)$ \\
\hline & $>$ Rp 4.000.000,00 & $1(4,2 \%)$ & $3(10,7 \%)$ & $1(6,7 \%)$ & $1(33,3 \%)$ \\
\hline Usia Awal & 10-15 tahun & $11(45,8 \%)$ & $12(42,9 \%)$ & $10(66,7 \%)$ & $2(66,7 \%)$ \\
\hline \multirow[t]{3}{*}{ Merokok } & 16-20 tahun & $12(50 \%)$ & $14(50 \%)$ & $4(26,7 \%)$ & $1(33,3 \%)$ \\
\hline & 21-25 tahun & - & $1(3,6 \%)$ & $1(6,7 \%)$ & - \\
\hline & 26-30 tahun & $1(4,2 \%)$ & $1(3,6 \%)$ & - & - \\
\hline
\end{tabular}

Mahasiswa mengetahui bahaya-bahaya yang dapat ditimbulkan dari pengkonsumsian rokok melalui media iklan dan label peringatan pada kemasan rokok itu sendiri. Namun, mahasiswa menganggap bahaya tersebut akan timbul jauh di masa yang akan datang. Mahasiswa belum merasakan bahaya akibat rokok secara langsung, oleh karena itu mereka tidak terlalu memperhatikan kesehatannya yang terganggu akibat rokok yang mereka konsumsi ${ }^{16,17}$. Label peringatan yang sudah tertera jelas pada kemasan rokok pun tidak meningkatkan kesadaran mahasiswa (perokok) akan kesehatannya ${ }^{18}$. 
Dwinta, Eliza

Karakteristik dan Status Ketergantungan Perokok Aktif terhadap Nikotin

Harga rokok saat ini mencapai Rp 25.000,00 per bungkus dengan isi $16-20$ batang rokok, jika masyarakat mengkonsumsi rokok perhari satu bungkus maka dalam satu bulan (30 hari) biaya yang dikeluarkan untuk membeli rokok adalah sebesar $\mathrm{Rp} 750.000,00^{2}$. Informasi tersebut mendukung karakteristik responden, yaitu perokok aktif terbanyak dalam penelitian ini memiliki pendapatan atau uang saku antara Rp 1.000.000,00 sampai dengan $\mathrm{Rp} 2.000 .000,00$ pada masing-masing tingkat ketergantungan responden terhadap nikotin. Sehingga, responden dengan pendapatan kurang dari Rp 1.000.000,00 akan lebih sedikit membeli rokok dibandingkan dengan responden dengan pendapatan lebih. Pada tingkat ketergantungan tinggi terhadap nikotin, hanya satu responden $(33,3 \%)$ yang memiliki pendapatan sebesar Rp 4.000.000,00. Berdasarkan kuesioner FTND, semakin banyak jumlah rokok yang dikonsumsi dalam sehari, akan meningkatkan total nilai yang akan berpengaruh pada tingkat ketergantungan terhadap nikotin.

Responden mengawali konsumsi rokok pada usia 16-20 tahun (50\%) dan sekarang responden tersebut memiliki ketergantungan rendah (12 responden) dan rendah hingga sedang terhadap nikotin (14 responden) (Tabel 3). Responden dengan ketergantungan sedang (10 responden) dan tinggi ( 2 responden) terhadap nikotin paling banyak mengawali merokok pada usia 10-15 tahun (66,7\%). Remaja yang merokok ingin menggambarkan identitas kepada orang-orang di lingkungannya dan cenderung memiliki persepsi yang lebih rendah terhadap risiko merokok atau bahaya merokok, sehingga remaja berani untuk mengawali kebiasaan merokok tanpa memikirkan dampak kesehatan di kemudian hari ${ }^{19}$.

Pada usia 10-20, seseorang masih mengalami dan memiliki pengaruh sosial yang memberikan efek langsung dari pengkonsumsian rokok. Pengaruh sosial yang dimaksud adalah dari perilaku dan kebiasaan orang di lingkungan hidupnya, seperti orang tua atau teman berkumpulnya ${ }^{20}$. Lingkungan sangat mempengaruhi seorang remaja karena remaja cenderung mengaitkan perilakunya sendiri dengan perilaku orang-orang di sekitarnya ${ }^{21}$. Orang tua juga memiliki pengaruh yang cukup banyak terhadap kebiasaan merokok anaknya, karena semakin lama durasi merokok orang tua dapat meningkatkan kemungkinan remaja untuk memiliki kebiasaan merokok yang lebih berat ${ }^{22}$.

Semakin muda usia seseorang menjadi perokok, akan semakin sulit berhenti merokok. Efek dari pengkonsumsian rokok ini disebut dengan dose-response effect. Dampak kesehatan akibat rokok akan terasa setelah 10-20 tahun setelah seseorang menggunakan rokok $^{23}$. FTND yang digunakan sebagai salah satu alat untuk mengidentifikasi 
tingkat ketergantungan nikotin ini penting untuk perencanaan pengobatan, terutama bagi perokok yang ingin menghentikan kebiasaan merokok ${ }^{24}$. Hal ini menjadi penting dan dapat dijadikan salah satu parameter untuk melakukan promosi kesehatan terkait peningkatan kesehatan bagi perokok, karena promosi kesehatan mengupayakan perubahan perilaku dan memfasilitasi perubahan perilaku ${ }^{25}$. Promosi kesehatan memiliki peran dalam perubahan perilaku dengan memanfaatkan unsur komunikasi kepada individu sehingga dapat memberikan keyakinan dalam menentukan sikap untuk menyelesaikan suatu masalah ${ }^{26}$.

\section{KESIMPULAN DAN SARAN}

Status ketergantungan perokok terhadap nikotin di wilayah Kota Yogyakarta dengan sampel perokok aktif yang merokok di tempat umum memiliki sebaran sebagai berikut: $40 \%$ responden memiliki ketergantungan rendah hingga sedang; 34,3\% responden memiliki ketergantungan rendah; $21,4 \%$ responden memiliki tingkat ketergantungan sedang, dan 4,3\% responden memiliki tingkat ketergantungan tinggi terhadap nikotin.

Saran dari penelitian ini adalah untuk peneliti selanjutnya dapat melakukan penilaian terhadap tingkat ketergantungan perokok terhadap nikotin dengan metode lain, sehingga dapat lebih menggambarkan tingkat ketergantungan terhadap nikotin dari variabel yang lebih luas.

\section{DAFTAR PUSTAKA}

1. Sundari Rini, Widjaya Dinyar Supiadi, Aditia N. Lama Merokok dan Jumlah Konsumsi Rokok terhadap Trombosit pada Laki-laki Perokok Aktif. Jurnal Kesehatan Masyarakat Nasional. 2015;9.

2. Kristina SA, Trung VQ, Permitasari NPAL, Dwinta E, Rahman F. Individual, Social and Psychological Characteristics of Smoking Cessation Behaviors: A Systematic Review. Global Journal of Health Science. 2018;10(10):55.

3. Ambarwati, Khoirotul Ayu U, Kurniawati Fifit, Diah Tika K, Saroh D. Media leaflet, video dan pengetahuan siswa SD tentang bahaya merokok. Jurnal Kesehatan Masyarakat. 2014;10(1).

4. WHO. Tubuh tembakau 2019.

5. Kesehatan K. Perilaku merokok masyarakat indonesia. Kementerian Kesehatan Republik Indonesia 2014.

6. Setiawan Agus Heri, Prabandari Yayi Suryo, Andono AR. Implementasi program rukun warga bebas rokok di Yogyakarta Berita Kedokteran Masyarakat Journal. 2017;33.

7. Pemerintah P. Peraturan Pemerintah tentang Pengamanan Rokok Bagi Kesehatan. In: Pusat P, ed; 2003.

8. J JM. Why people smoke. British Medical Journal. 2004;328:277-279.

9. Liem A. Pengaruh nikotin terhadap aktivitas dan fungsi otak serta hubungannya dengan gangguan psikologis pada pecndu rokok. Buletin psikologi. 2010;18:37-50. 
10. $\mathrm{Ng} \mathrm{N}$, Weinehall $\mathrm{L}$, Ohman A. 'If i don't smoke, i'm not a real man'-Indonesian teenage boys'views about smoking. Health education research. 2007;22:795-804.

11. Kardia SLR, Pomerleau CS, Rozek LS, Marks JL. Association of parental smoking history with nicotine dependence, smoking rate, and psychological cofactors in adult smokers. Addictive Behaviors. 2003;28(8):1447-1452.

12. Stickley A, Koyanagi A, Roberts B, Leinsalu M, Goryakin Y, McKee M. Smoking status, nicotine dependence and happiness in nine countries of the former soviet union. Tobacco control. 2015;24:190-197.

13. Pennanen $\mathrm{M}$, Broms $\mathrm{U}$, Korhonen $\mathrm{T}$, et al. Smoking, nicotine dependence and nicotine intake by socio-economic status and marital status. Addictive Behaviors. 2014;39:1145-1151.

14. Yulianto EA. Persepsi siswa smk kristen (ti) salatiga tentang bahaya merokok bagi kesehatan. Journal of Physical Education, Sport, Health and Recreations. 2015;4(5):1807-1813.

15. Kimberly Waters, Harris Karl, Sandra Hall, Nilaman Nazir, Waigandt A. Characteristics of social smoking mong college students. National Institute of Health. 2006;55(3):133139.

16. UR A, SP L. Perceived risk of cigarette smoking among college students. Nepa Healt Res Counc Journal. 2011;9(19):176-180.

17. Prayogi Ririh, Widjanarko Bagoes, Tirto HB. Deskripsi sikap mahasiswa perokok di fakultas $\mathrm{x}$ semarang terhadap peringatan kesehatan pada bungkus rokok. Jurnal Kesehatan Masyarakat. 2015;3:657-668.

18. Widati S. Efektivitas pesan bahaya rokok pada bungkus rokok terhadap perilaku merokok masyarakat miskin. Jurnal Promkes. 2013;1(2):105-110.

19. Chotidjah S. Pengetahuan tentang rokok, pusat kendali kesehatan eksternal dan perilaku merokok. Makara, Sosial Humaniora. 2012;16:49-56.

20. Simons-Morton BG, Farhat T. Recent findings on peer group influences on adolescent smoking. Journal of Primary Prevent. 2010;31:191-208.

21. Holliday JC, Rothwell HA, Moore LA. The realtive importance of different measures of peer smoking on adolescent smoking behavoir: Cross-Sectional and longitudinal analyses of a large british cohort. Journal of Adolescent Health. 2010;47:58-66.

22. Mays D, Gilman SE, Rende R, Luta G, Tercyak KP, Niaura RS. Parental smoking exposure and adolescent smoking trajectories. Pediatrics. 2014;133:983-991.

23. Yashinta SOG, Delmi S, Yuniar L. Hubungan Merokok dengan Kejadian Hipertensi pada Laki-laki Usia 25-65 Tahun di Kota Padang. Jurnal Kesehatan Andalas. 2015;4(2):434440.

24. Weber CF, Hatschbach P, Pithan SA, Dullius AldS. Measure nicotine dependence by the fagerström test for nicotine dependence. RGO - Revista Gaúcha de Odontologia. 2017; 65(3):208-215.

25. Putra A, Hasan I. Peranan promosi kesehatan dalam pengendalian perokok aktif. Jurnal IImiah Mahasiswa FISIP Unsyiah. 2018;3:914-926.

26. M.P.P C, Engkeng S, Asrifuddin A. Pengaruh promosi kesehatan terhadap pengetahuan dan sikap merokok pada pelajar laki-laki di smk negeri 2 kota bitung. Jurnal KESMAS. 2018;7. 